\title{
CENTENÁRIO DO NASCIMENTO DE MONSENHOR CELSO TAVARES DA SILVA - UMA FIGURA ÍMPAR DA HISTÓRIA DA UNIVERSIDADE CATÓLICA DE VISEU
}

(Cedrim do Vouga, 29 de fevereiro de 1916 - Lisboa, 7 de junho de 1996)

No dia 29 de fevereiro de 2016, cumpriram-se 100 anos sobre o nascimento de Monsenhor Celso Tavares da Silva, o principal responsável pela criação da Universidade Católica em Viseu. Com o intuito de celebrar o centenário do seu nascimento, a Universidade Católica de Viseu decidiu evocar esta figura ímpar da sua história com uma singela homenagem concretizada através de uma exposição, na Biblioteca D. José Pedro da Silva, da sua produção bibliográfica enquanto arqueólogo, e, em 7 de junho, dia do seu falecimento, descerrou uma placa que dá o seu nome à sala de leitura da referida Biblioteca.

Este homem notável pela sua cultura, humanismo, carisma e bondade, de quem tive o privilégio de ser amigo e com quem convivi ao longo de 15 anos na Universidade Católica de Viseu - a Católica de Monsenhor Celso - marcou de forma indelével esta instituição ao longo de muitos anos. Não é exagero dizer-se que é a sua Católica, pois ele foi, indubitavelmente, e por duas razões principais, a alma desta nossa Alma Mater: a primeira porque se assumiu como um dos principais impulsionadores da ideia da criação em Viseu de um Pólo da Universidade Católica, que acabaria por nascer essencialmente em resultado de todo o seu entusiasmo contagiante, empenho, perseverança e determinação - D. António Monteiro escreveu em 1996, no vol. 5 da Revista Máthesis, dedicado a Monsenhor Celso, que ele era "um daqueles homens que nasceu para ser "parteiro", sempre ao serviço da vida" (p.15) -; a segunda porque foi o seu principal obreiro, conseguindo, com a sua persistência sempre entusiástica, continuar a alimentar a recém-criada Universidade, como seu Secretário-Geral, ao longo de quase década e meia (1980-1994), transformando uma secção da Faculdade de Filosofia de Braga, que arrancou em 29 de outubro de 1980 com apenas uma licenciatura - Humanidades - e com 56 alunos, num Pólo 
autónomo que, em 1994, data da sua retirada, já era composto por duas Escolas - a Faculdade de Letras e o Instituto Universitário de Desenvolvimento e Promoção Social - que ofereciam seis cursos de licenciatura: Humanidades, Português-Francês, Francês-Inglês, PortuguêsHistória, Inglês-Alemão e Gestão e Desenvolvimento Social.

Nihil est annis uelocius ("nada é mais veloz que os anos") diz Ovídio nas Metamorfoses (10. 520). E é verdade. De facto, parece-me que foi há pouco tempo que contactei pela primeira vez com Monsenhor Celso. E já lá vão 35 anos... Aconteceu em 1981, quando me fez a então exigida entrevista de acesso ao ano propedêutico do curso de Humanidades. Recordo desse momento a simpatia e a cordialidade de um homem que transformou um momento de avaliação numa afável e agradável conversa. Desde então, a minha vida foi-se cruzando regularmente, ao longo de 15 anos, com a figura carismática de Monsenhor Celso, durante 5 anos como aluno e 10 como docente da Universidade Católica de Viseu. Tive, pois, o privilégio de privar de perto, durante década e meia, com este homem ímpar pela sua retidão de caráter, bondade e humanismo, e de admirar a sua cultura de verdadeiro mestre, a sua disponibilidade sempre generosa e a força inquebrantável que o animava.

Estas qualidades de Monsenhor Celso Tavares da Silva eram unanimemente reconhecidas e admiradas por toda a comunidade académica que teve a fortuna de com ele contactar e sentir a sua afabilidade e humanidade. Por isso mesmo a sua Universidade homenageou-o, em 1996, dedicando-lhe dois volumes das suas revistas científicas: o ${ }^{\circ} 5$ da Revista Máthesis da Faculdade de Letras e o $\mathrm{n}^{\circ} 4$ da Revista Gestão e Desenvolvimento do Instituto Universitário de Desenvolvimento e Promoção Social.

Agora, com a atribuição do seu nome à sala de leitura da Biblioteca D. José Pedro da Silva, procurou-se contrariar o habitual efeito inexorável do tempo e perpetuar a memória de um grande mestre que, com um entusiasmo contagiante, tudo fez para a materialização da obra que sonhou. Deste modo, o seu nome perdurará, in aeternum, indissoluvelmente ligado à Alma Mater viseense, não só como seu fundador mas também como um dos vultos mais marcantes que por ela passaram.

\section{Aires Couto}

Presidente do Centro Regional de Viseu da UCP 